\title{
INNOVATION INFRASTRUCTURE AS A TOOL FOR THE DEVELOPMENT OF REGION'S SOCIOECONOMIC SYSTEM
}

This article is based on the analysis of domestic and foreign experience of innovation infrastructure. It identifies the main problems of modern development of innovation systems and the reasons for their poor performance in the Russian regions. The approach using of innovation infrastructure as a tool of modernization of regional socioeconomic systems is proposed. The author emphasizes the urgency of ensuring sustainable development of Russia not only through the development of breakthrough technologies in the production of structural materials with preset characteristics, genetic engineering, molecular biology, but also through the rapid development of technology is directly related to the modernization of the industrial complex. The necessity of the correlation between socioeconomic and innovation policies is proved. Common paths and directions of increase of efficiency of the existing and created objects of innovation infrastructure in Russia taking into account the actual needs and priorities of socioeconomic development of the regions are outlined.

Keywords: effectiveness of innovation infrastructure, innovation systems, technological modernization of region, innovation policy 
Necessary condition for Russian economy development according to the innovative scenario is developing favorable institutional prerequisites, one of which - creation of effectiveness of innovation infrastructure contributing to the acceleration of innovation process in regions. The world practice analysis of creation and development innovation infrastructure shows that actively participating in the complex solution of regional socioeconomic problems the Hi-Tech parks, innovative centers and other innovation systems carry out functions of the modernization centers, at the same time bringing into focus the scientific and technical and innovative capacity of territories as the main resource of their revival, normalization of reproduction processes, ensuring socioeconomic growth [6, page 26-27]. That is why since 1970th in both developed and developing countries the creation of innovation infrastructure has become one of the priorities of economic policy.

The classic issue showing powerful revitalizing and modernizing influence of innovation systems on socioeconomic processes is the emergence of nowadays the world renowned American centers of microelectronics of Route 128 and Silicon Valley regions in the economically poorly developed regions, in the 50th years of the twenty century. Germany, France and many other countries purposefully and successfully used possibilities of innovation systems as growing-points and tool of the state socioeconomic policy (tab. 1). Currently, the innovation infrastructure in Israel is dynamically growing. Development of a scientific and technological system of this country has become an important component of the "model society" concept focused on economic modernization, ensuring economic and technological independence of Israel, and transformation of the country into one of the world centers of the latest technologies, the breakthrough science and culture.

All countries, which made a statement as global producers and exporters of high-technology products, have the well-developed network Hi-Tech parks and other innovation infrastructure objects. These objects contribute to stabilization of the economic situation; accelerate the processes of development and distribution of new technologies; promote an increase of the non-material and immaterial factors of production, informational support of society.

For instance, in Germany, one of the leading world power in developing science and engineering, the innovation systems have played an important role in formation of science industries where nowadays nearly 2.5 million people work. Thus, the Hi-Tech park Berlin Adlershof, created in 1991, 15 years later turned into the largest center of innovative activity in Europe, united 12 research institutes, 6 institutes of University of Humboldt and more than 500 enterprises specializing in the area information, bio- and optical technologies, and also new materials [1].

Russia did not remain uninvolved of the world widely distributed process of innovation systems' formation. Now the Russian Federation takes the 5th place in the world in the number of technoparks as the most popular form of the organization of innovative activity.

Table 1

Main reasons for creation of $\mathrm{Hi}$-Tech parks in a world practice

\begin{tabular}{|l|l|}
\hline \multicolumn{1}{|c|}{ Name of innovative infrastructure } & \multicolumn{1}{c|}{ Reasons for creation } \\
\hline $\begin{array}{l}\text { Silicon Valley (California), Route 128 (Massachusetts) } \\
\text { The Research Triangle (North Carolina), Evanston } \\
\text { Research Park (State of Illinois) in USA }\end{array}$ & $\begin{array}{l}\text { Decreasing product competitiveness, producing by conventional ways. } \\
\text { Need to overcome the crisis connected to restructuring of the economy. } \\
\text { «rain drain» to abroad. } \\
\text { Reduction in production and workplaces }\end{array}$ \\
\hline $\begin{array}{l}\text { Science and Technology Park Berlin Adlershof, } \\
\text { Technology park in Dortmund city, the technological } \\
\text { centers in Schwerte, Aachen, Hanover, Munich, the } \\
\text { Silicon Valley near Dresden, (Germany) }\end{array}$ & $\begin{array}{l}\text { Opportunities development exhaustion in steelmaking industry and } \\
\text { other branches of the heavy industry. } \\
\text { Need for diversification of production. } \\
\text { Development stimulation of new technologies and innovations }\end{array}$ \\
\hline $\begin{array}{l}\text { Sofia Antipolis in Nice, the Lyons technopolises, } \\
\text { science and technology park in Grenoble (France) }\end{array}$ & $\begin{array}{l}\text { Need for approaching of the enterprises and research institutes. } \\
\text { Creation the conditions for the access of small and medium-sized } \\
\text { enterprises to technical knowledge. } \\
\text { Ensuring the growth of competitiveness of production }\end{array}$ \\
\hline $\begin{array}{l}\text { Science parks of Aston, Kiel, Cambridge, Bradford } \\
\text { universities (Great Britain) }\end{array}$ & $\begin{array}{l}\text { The overcoming of decline of traditional industry sectors (coal-mining, } \\
\text { steel industry, metallurgy) } \\
\text { Creation of the flexible innovative business }\end{array}$ \\
\hline $\begin{array}{l}\text { Technopolises in Toyama, Yamaguti, Kumamoto, } \\
\text { Hamamatsu, etc. (Japan) }\end{array}$ & $\begin{array}{l}\text { Necessity for the carrying out restructuring with orientation to the } \\
\text { knowledge-intensive industry sectors } \\
\text { Need for acceleration of technologies' transfer. } \\
\text { Fight for leadership of hi-tech production in the world market. } \\
\text { Creation of growing points for ensuring economic development }\end{array}$ \\
\hline
\end{tabular}


The most complete data on the condition of the Russian innovation systems are submitted on a website of the National center for monitoring of innovation infrastructure of scientific and technical activity and regional innovative systems. According to this site, as of early 2013 in Russia were over $150 \mathrm{Hi}$-Tech parks, 106 innovation and technological centers, and 122 engineering and technology transfer centers [8]. Besides this, in the Russian Federation 14 larger territorial innovative systems - science cities [7, page 198] are created. Currently, there are about 70 more "closed" and "half-closed" territorial entities, which in the long term can become the base for the formation of innovation systems, as well. Additionally, in 2005 started the large-scale project on clusters' creation in many regions of the Russian Federation where the special role is allocated for development and use of innovation infrastructure.

At the same time, in spite of such impressive quantity and enviable variety of innovation infrastructure objects, there are many problems in their functioning and development. The main one is the low efficiency of created objects. From the socioeconomic point of view, the majority of national Hi-Tech parks and other innovation systems cannot be called successful. Thus, since 1990 on the basis of higher education institutions have been created 76 science and technology parks, however, in 2009 the state accreditation received only 21 of them (28\%) [18]. Only in 12 of Hi-Tech parks, the number of workplaces is more than $200^{1}$. Hence, they yet have no essential impact on the creation of new workplaces. The financial and economic indicators of the vast majority of high school Hi-Tech parks also are very modest, except of five, their annual volume of production is: 4.8 billion rubles - in Moscow State University HiTech park; 3.0 billion rubles - in Zelenogradsk Hi-Tech park at Moscow State University of Technology and Management; 1 billion rubles - in Moscow Power Engineering Institute $\mathrm{Hi}^{-}$ Tech park; 0.5 billion rubles - in Hi-Tech park of Moskvorechye (Moscow Engineering Physics Institute) and 0.45 billion rubles - in Hi-Tech park of Saint Petersburg State Electrotechnical University (St. Petersburg) [18].

\footnotetext{
${ }^{1}$ It is, first of all, Zelenogradsk Hi-Tech park at Moscow State University of Technology and Management - 2700 people; Moscow State University Hi-Tech park - 2500 people; Moscow Power Engineering Institute Hi-Tech park - 700 people; "Volga-technique" Hi-Tech park (Saratov State Technical University) - 600 people; Tmosk Hi_Tech park - 450 people; Moskvorechye Hi-Tech park (Moscow Engineering Physics Institute) -350 people; Hi-Tech park of Saint Petersburg State Electrotechnical University - 360 people [17].
}

Selection of the Hi-Tech parks by the resident enterprises is not always justified and successful that can be shown on the example of Hi-Tech of the Central Ural region. Among the enterprises of the Ural technoparks, there are some innovatively active, successfully proved in the market of high technologies and innovative production.

Among them are the technopark enterprises "High technologies of mechanical engineering" entering into the Ural machine-building corporation "Pumorii-SIZ", annually letting out the machine equipment and the tool more than on 1 billion rubles; the resident enterprises of the innovation and technological center "Akademichesky" (the volume of output of 750 million rubles a year), and also a number of the enterprises releasing instrumentation and sensors within "Instrument making" Hi-Tech park, etc. But in Hi-Tech parks, there are not a rarity having both not innovation and non-core residents: car service, sanitary engineering services, trade enterprises, etc.

Therefore, successfully functioning $\mathrm{Hi}$-Tech parks at higher education institutions may be called only 5 out of almost 80 operating ones that indicate the experiment failure on their creation.

Innovative activity of others, larger version of innovation infrastructure - the Russian science cities also does not seem to be remarkable. Even the share of innovatively active enterprises carrying out technological innovations is only slightly less than innovatively active enterprises not being their residents. Thus, in 2010 this indicator in science cities is $11.3 \%$, and the average one in the Russian Federation reached 8\%. For comparison: by data for 2009 in Finland the share of the organizations carrying out technological innovations is $55.4 \%$, in Sweden $-50.9 \%$, and even in Bulgaria $-23.8 \%$ [10, page 11]. In science cities, specific weight of shipped innovative production in total production is low at the moment. It counted a little more than $12 \%$ (tab. 2).

Today the technoparks of high technologies are developing more successfully. They have been developed in the Russian Federation under a supervising of the Ministry of Telecom and Mass Communications since 2006. Within the special program the organization of 12 technoloparks, which have to unite the enterprises of high-tech industries, including nano- bio- information and other technologies in 10 regions [19] is planned. Following objects of technoparks are already have put into operation: "The West Siberian innovative center" in the Tyumen region; technoparks in the Republic of Tatarstan (Kazan) - "IT park" and the first stage "the Technopolis "Himgrad"”; the first 
Table 2 The main indicators of innovative activity of the industrial production organizations carrying out technological innovations in science cities, $\%$

\begin{tabular}{|l|c|c|c|c|c|c|c|c|}
\hline \multicolumn{1}{|c|}{ Indicator } & \multicolumn{3}{c|}{ Science City } & \multicolumn{4}{c|}{ The RF } \\
\cline { 2 - 9 } & $\mathbf{2 0 0 7}$ & $\mathbf{2 0 0 8}$ & $\mathbf{2 0 0 9}$ & $\mathbf{2 0 1 0}$ & $\mathbf{2 0 0 7}$ & $\mathbf{2 0 0 8}$ & $\mathbf{2 0 0 9}$ & $\mathbf{2 0 1 0}$ \\
\hline $\begin{array}{l}\text { The share of the in-novation-active organizations } \\
\text { carrying out technological innovations }\end{array}$ & 8.9 & 8.2 & 12.2 & 11.3 & 8.5 & 8.0 & 7.7 & 7.9 \\
\hline $\begin{array}{l}\text { The share of the shipped innovative goods in } \\
\text { volume of the shipped goods of innovatively active } \\
\text { organizations }\end{array}$ & 19.5 & 21.3 & 10.4 & 12.6 & 10.4 & 9.8 & 9.3 & 8.9 \\
\hline $\begin{array}{l}\text { The share of expenses for technological } \\
\text { innovations in the volume of the shipped goods of } \\
\text { innovatively active organizations }\end{array}$ & 9.0 & 3.2 & 7.3 & 8.8 & 2.8 & 3.1 & 4.3 & 3.4 \\
\hline
\end{tabular}

Source: [10, P. 81].

stage of technoparks in Novosibirsk and Kemerovo areas.

Following the results of 2011, 19.5 billion rubles, including 15.5 billion rubles - public funds were invested into the infrastructure of technoparks. 9000 new workplaces are so far created, and from 2009, the revenue of the companies residents of technoparks, according to the data received from authorized bodies of the Russian Federation subjects was more than 39 billion rubles including 2011 year [15]. However adjusted totals on development of technoparks in the sphere of high technologies cannot be made so far. The world practice testifies that their real return can be expected not earlier than in 10 years after their creation.

Therefore, at the moment Russia has rather wide experience of creation of innovation infrastructure objects, there is an extensive network of innovation systems. But its development did not lead neither to growth of small innovative business, nor to the population of the innovative activities in regions, to a noticeable increase in a share of hi-tech production in total production and export.

Let us try to understand the reasons of low efficiency of innovation infrastructure in the Russian Federation.

The main reason seems to be from a lack of thought-over scientifically reasonable strategy of innovative development of the Russian Federation. Innovations and innovation activity are still perceived in the RF, not as a basis of modern socioeconomic transformations in the country and its regions, but only as a certain fashionable trend. But as it is known, the fashionable trend is shortlived; therefore, the attitude towards it remained light. The data on a level of innovation activity financing in the Russian Federation do testify to this point. Thus, according to the expenses on research and development the Russian Federation trailed the USA by 17 times, the European Union
Table 3

Expenses for the innovation activity development in Russian Federation, billion rubles.

\begin{tabular}{|l|c|c|c|}
\hline \multicolumn{1}{|c|}{ Item of expenditure } & $\mathbf{2 0 1 0}$ & $\mathbf{2 0 1 2}$ & $\begin{array}{c}\mathbf{2 0 1 3} \\
\text { (forecast) }\end{array}$ \\
\hline Skolkovo innovation centre & 3.99 & 10 & 20 \\
\hline Technology and innovation zones & 11.8 & 7.7 & 10 \\
\hline Sience Cities & 0.54 & 1 & 3 \\
\hline Innovation clusters & 0.1 & 1 & 10 \\
\hline Altogether: & 16.43 & 19.7 & 43 \\
\hline
\end{tabular}

countries - by 12 times, China - by 6.4 times and even India - by 1.5 times [17].

Dynamics of expense changes in the innovation infrastructure development in the Russian Federation in 2010-2013 is reflected in table 3. The volume of investments in innovation systems in three years has to increase very considerably in 2.6 times. Nevertheless, it is obvious, even at such growth rates of investments the problem of effective innovation infrastructure creation will be hardly solved by 2013 (and even by 2020) as they are not sufficient to overcome lag on a level of innovative development from the developed countries.

There is also an obvious unevenness in the financing of the innovation infrastructure objects, strengthening the problems existing in national practice and distortions in innovative development. It is known, for example that the state budget invests generously in the project of the innovation center Skolkovo. For these purposes, it is planned to allocate 85 billion rubles up to 2015 [16]. For comparison: approximately the same time the implementation of the program of Hi-Tech parks creation (its end is planned in 2014) is carried out. However regional budgets from 2007 up to $2011 \mathrm{fi}-$ nanced much less in four technoparks ${ }^{1}$ (in Kazan,

\footnotetext{
${ }^{1}$ The revenue of the resident companies of Hi-Tech parks from 2009 up to 2011 exceeded 39 billion rubles (an accruing result). As mr. Massukh, the Minister of Telecommunications of Russia
} 


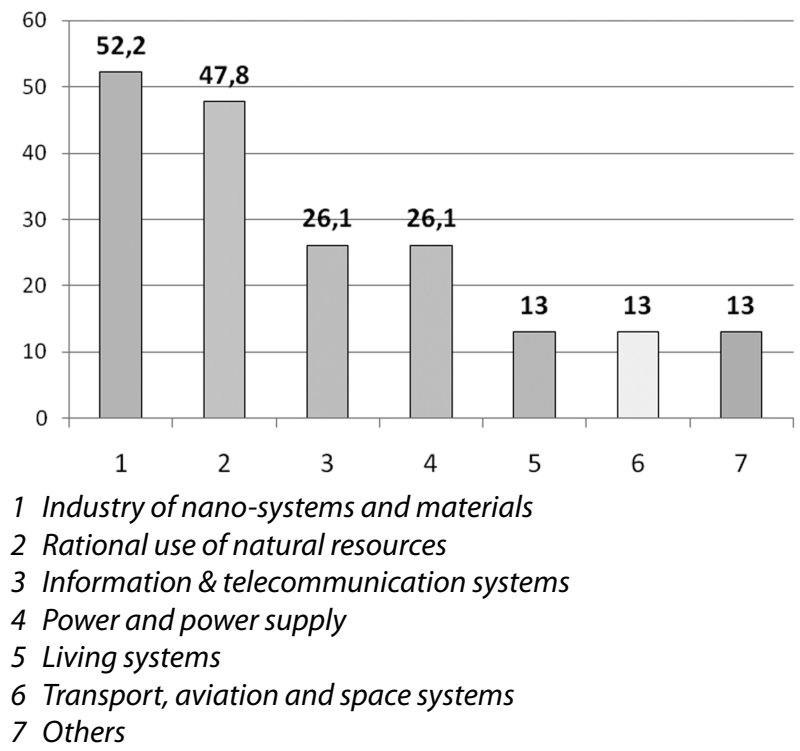

Fig. Distribution of the UB of the RAS organizations carrying out research and advanced development over preferred direction, as a percentage of the scientific organizations

Nizhny Novgorod, Novosibirsk and the Tyumen region), infrastructure actively developing and already filling up than in Skolkovo (less than 20 billion rubles, including 7 billion rubles of the federal budget, 8.5 billion of regional budgets and 4 billion rubles of private investors [16]).

On the basis of the leading academic institutes, the innovation and technology center is created. However, at the moment it's only a place for research and development result approbations. At the present stage, it is obviously necessary and important to expand the range of its activity having turned it into the large regional center of the advanced production technologies. With the assistance of the Institute of Economics of the UB of the RAS, the relevant project is developed.

Confusion of the legal framework in the sphere of innovation activity acts as a powerful brake for the development of the effective infrastructure in the Russian Federation. In the current legislation, there is no clear vision of the purposes, prospects, priorities, and the stages of innovative and technological development. In the concept of socioeconomic development strategy of the Russian Federation until 2020 [5] and other governmental documents the role of innovation infrastructure as a key instrument for realization of the state innovation policy is not included, the status of the main subjects of innovation activity is not defined, economics and other measures of the state support of innovation processes are not assigned.

reported in May 2012, the accrued taxes of operating tekhnoparks came up with the federal budget amount of financing [16].
Federal laws on innovation policy and Hi-Tech parks still are in the stages of infinite completion and discussion. All this slows down the processes of the innovative opportunities updating in the Russian regions.

One of the main reasons for an inefficiency of the operating innovation infrastructure objects in the Russian Federation is covered also in a lack of process coordination of their formation. In Russia, there is not the single authority, which responsible for their development, and, as a result, there is not a work strategy and a thought-over organization strategy. Today, construction of the innovation infrastructure objects is assigned to several ministries, each of which carries out its activity independently.

Thus, the Ministry of Education and Science of the Russian Federation is engaged in development of innovation infrastructure at higher education institutions and scientific research institute; The Ministry of information technologies and communication of the Russian Federation took under its wing the IT Hi-Tech parks' construction; The Ministry of Economics, developments and trade realizes the projects of special economic zones (SEZ), etc. As a result of their inconsiderate actions are a lot of innovation infrastructure objects, without any their connection to the valid requirements of long-term socioeconomic development of the Russian Federation and its regions.

Absence of the single coordinating body directing the development of innovation infrastructure, besides making more confusion in economic management and placement of managing subjects, provokes also strengthening the a gap between science and production existing in the Russian Federation.

At last, another reason of a low efficiency of innovation infrastructure is extreme unevenness of their territorial location. Being thinking of $\mathrm{Hi}^{-}$ Tech park vogue, science cities and other innovative systems, Russia construct and continues to construct them, first of all, in capital cities and the central regions (tab. 4).

Central federal district significantly exceeds other federal districts by the quantity of the created innovation systems (over nearly $2 / 5$ of all innovation infrastructure objects fall to its share), on the second place - the Volga federal district concentrated $1 / 4$ of all innovation infrastructure objects of the Russian Federation, including nearly $30 \%$ of all Hi-Tech parks.

Ural Federal District, despite the developed scientific and technical innovative and industrial capacity, is only on the fifth place according to the number of innovation infrastructure ob- 
Table 4

Distribution of innovation infrastructure objects over federal districts of the Russian Federation [8]

\begin{tabular}{|c|c|c|c|c|}
\hline Federal district & 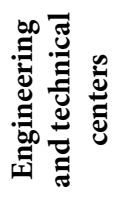 & $\begin{array}{c}\text { Hi-Tech } \\
\text { parks }\end{array}$ & 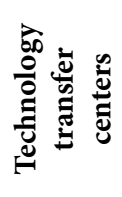 & Total \\
\hline Central & 38 & 60 & 41 & 139 \\
\hline Privolzhsky & 8 & 42 & 25 & 75 \\
\hline Siberian & 20 & 9 & 14 & 43 \\
\hline North Western & 18 & 10 & 12 & 40 \\
\hline Ural & 3 & 22 & 6 & 31 \\
\hline South & 8 & 8 & 11 & 27 \\
\hline Far East & 7 & 4 & 7 & 18 \\
\hline North Caucasian & 4 & 2 & 6 & 12 \\
\hline Russian Federation & 106 & 157 & 122 & 385 \\
\hline
\end{tabular}

jects. Then, the Ural Federal District accounts for about 31 of innovation infrastructure objects. It is 4.5 times less, than in the Central Federal District. The gap in a number of innovation infrastructure objects between the Center and such federal districts, as Youzhny (5 times), Far East (8 times), and North Caucasian (12 times) is big.

Obvious distraction in the location of the innovative development centers in the Russian Federation lead to the fact that innovative systems do not help to the production decentralization and unite the level socioeconomic development in different regions as it is in Japan, USA and some other countries. On the contrary, concentration of innovative infrastructure objects mainly around capital cities and certain megalopolises even more strengthen interregional distinctions and contradictions on such important socioeconomic issues, as the volumes of investment, level of income and a social standard of living, creation of highly paid workplaces, etc.

The analysis of development problems of innovative infrastructure shows that the issue of creation of effective innovative systems cannot be solved separately from a strategy of socioeconomic development. Innovative infrastructure is the important instrument of innovative processes activation and modernization of the economy in the regions. Hi-Tech parks, the centers of a transfer of technologies and other innovative systems are a kind of catalyst of socioeconomic development and an important element of the modern economy allowing to create the socioeco- nomic environment, which provides a sustainable development of scientific and technological and production business. In this regard in relation to Russia, the development of innovative infrastructure should be referred to one of the key issue of a modern state policy.

Creation of innovative infrastructure is the complex process, which has been closely connected to a development level, requirements and development priorities of regional socioeconomic systems. Arrangement of Hi-Tech parks, scientific and technological parks, innovative territories and other of innovative infrastructure objects demands a complex approach. As a high priority measures of improvement of the effectiveness of innovation infrastructure as mechanism of modernization are offered the following ones:

1) elaboration of innovation infrastructure development strategy of the Russian Federation with its focus on priorities and problems of socioeconomic development of certain regions on the long-term prospect;

2) at the level of the Russian Federation Government development and legislative consolidation the management of financial support of objects of innovation infrastructure, including the procedure for financing from the federal budget, and also tax discrimination and other privileges (on profit taxes, a value added, property, rent, municipal payments of not less than $50 \%$ of tax rates) [14, page 49-50];

3) development of the system of encouragement and motivation for the innovation systems and their residents introducing new technologies, focused on the solution of the modernization task of regional socioeconomic systems and, first of all, their basic productions;

4) creation of the single authority with financial powers controlling the innovation systems and their development. It is necessary to strengthen the activity coordination of Hi-Tech parks and other innovation infrastructure objects and optimization of their placement at the Government of the Russian Federation.

Realization of these measures in practice of public administration of innovation processes would help to transform the innovation infrastructure into the effective mechanism of socioeconomic policy directed to modernization of the Russian economy and strengthening of its capacity.

\section{References}

1. Germaniya. Tekhnoparki i klastery [Germany. Technoparks and Clusters]. Available at: http: //andshestopalov.livejournal. com/73524.html (date of access: 14.02.2013).

2. Golova I. M. (2012). Problemy formirovaniya innovatsionno-tekhnologicheskogo imidzha rossiyskikh regionov [Problems of Formation of Innovative and Technological Image of the Russian Regions]. Ekonomika regiona [Economy of Region], 2, $105-115$. 
3. Grinberg R.S. (2010). Osushchestvima li rossiyskaya modernizatsiya? [Whether the Russian Modernization is Possible or Not?] Zhurnal Novoy ekonomicheskoy assotsiatsii [Magazine of New Economic Association], 7, 144-146.

4. Innovatsionnaya aktivnost kompaniy RF ostayotsya krayne nizkoy [Innovation Activity of the Russian Federation Companies Remains Quite Low]. RIA Novozti [Russian International News Agency (RIA Novosti)] Available at: http://ria.ru/ nano/20130129/920362354.html\#ixzz2KtHW99pE

5. Kontseptsiya dolgosrochnogo sotsialno-ekonomicheskogo razvitiya Rossiyskoy Federatsii do 2020 goda. Utverzhdena razporyazheniyem Pravitelstva RF ot 17 noyabrya 2008 g. № 1662-p. [The Concept of Long-term Socio-Economic Development of the Russian Federation up to 2020. It is Approved as the Order of the Government of the Russian Federation on November 17, 2008 No. 1662-r.] Available at the legal reference system «Consultant Plus».

6. Kuklin A. A. Edited by: Chereshnyov V.A., Tatarkin A. I., Fyodorov M. V. (2012). Innovatsionnoye razvitiye kak osnova ekonomicheskogo rosta ekonomiki regiona [Innovation Development as the Basis of Economic Growth of the Economy of Region]. Ekonomicheskaya bezopasnost Rossii. Uroki krizisa i perspektivy rosta [Russia’s Economic Safety. Crisis Lessons and Growth Prospects ]. Vol.1. Yekaterinburg, Institute of Economiucs, UB of the RAS, 20-31.

7. Nauka Rossii v tsifrakh [Russian Science in Numbers] (2011). Moscow, TsISN [Centre for Science Research and Statistics], Moscow.

8. Natsionalnyy tsentr po monitoringu innovatsionnoy infrastruktury nauchno-tekhnicheskoy deyatelnosti i regionalnykh innovatsionykh system [National Center for Monitoring of Innovative Infrastructure of Scientific and Technical Activity and Regional Innovative Systems]. Available at: http://www.miiris.ru (date of access: 12.02.2013).

9. Reznikova A., Ptelevoy V. (2012). Finansirovaniye innovatsiy ne prineslo plodov dlya ekonomiki [The Financing of Innovations did not Bring Success for Economics]. RBC daily, 2012, 9 of February. Available at: http://www.rbcdaily.ru/politics/ 562949982767362

10. Gokhberg L.M. (Ed.) (2011). Rossiyskiy innovatsioonnyy indeks [Russian Innovation Index]. Vysshaya shkola ekonomiki [High School of Economics], Moscow.

11. Rossiyskiy statisticheskiy ezhegodnik [Statistical Yearbook of Russia] (2011). Moscow, Rosstat.

12. Strategiya razvitiya nauki i innovatsiy v Rossiyskoy Federatsii na period do 2015 goda. Utverzhdena Mezhvedomstvennoy komissiyey po nauchno-innovatsionnoy politike (protocol ot 15 fevralya 2006g. № 1) [Strategy of Development of Science and Innovations in the Russian Federation for the Period until the Year 2015. Approved by the Interdepartmental Committee on Science and Innovation Policy ()]. Available at: Стратегия развития науки и инноваций в Российской Федерации на период до 2015 года. Утверждена Межведомственной комиссией по научно-инновационной политике (the Protocol of February 15, 2006 No 1). Available at the legal reference system «Consultant Plus».

13. Kleyner G. B. (Ed.) (2002). Strategiya razvitiya predprinimatelstva v realnom sektore ekonomiki [Strategy of Enterprise Formation in the Real Sector of the Economy]. Moscow, Nauka Publ. House.

14. Sukhovey A.F., Golova I. M. (2010). Innovatsionnyye vozmozhnosti samorazvitiya regiona [Innovative Opportunities of Region Self-Developing]. Yekaterinburg, Institut Ekonomiki UrO RAN [IE, UB of the ras], 200.

15. Teknoparki [Technoparks]. Minsvyazi RF [Ministry of Communications of the Russian Federation]. Available at: http:// minsvyaz.ru/ru/directions/?direction=25

16. Tekhnoparki Rossii [Russia’s Technoparks]. Available at: http: tadviser.ru/ (date of access: 11.11.2011).

17. Untura G.A. (2011). Territorii innovatsiy: rasshireniye spectra vozmozhnostey [Territories of Innovations: Broaden Options]. ЭКО [EKO Journal], 11, 15-30.

18. Shukshunov V.E. Tekhnoparkovoye dvizheniye v Rossii. Opyt, tendentsii, perspektivy [Technopark Movement in Russia. Experience, Tendencies, Prospects]. Akkreditatsiya v obrazovanii [Accreditation in Education]. Available at: http:// akvobr.ru/ perspektivy_razvitija_tehnoparkov_v_rossii.html (date of access: 10.02.2013).

19. Shchegolev I. Federalnaya programma po sozdaniyu tekhnoparkov okazalas effektivnoy [The Federal Program on Creation of Technoparks was Effective.]. Available at: http://minsvyaz.ru/ru/news/index.php?id_4=42623.

\section{Information about the author}

Sukhovey Alla Filippovna (Yekaterinburg, Russia) - Doctor of Philosophical Sciences, Professor, Head of Sector of Social Innovation, the Institute of Economics of the Ural Branch of the Russian Academy of Sciences (620014, Yekaterinburg, Moskovskaya str., 29, e-mail: alla_suhovey@list.ru). 